\title{
Impact of Coastal Community Empowerment Development Project-International Fund for Agriculture
}

\author{
Imran Tajuddin $1 \bowtie$ \\ ${ }^{1}$ Economics and Development Studies, Faculty of Economics and Business, Universitas Muslim Indonesia \\ DOI : https://doi.org/10.37531/ecotal.v3i1.113
}

\begin{abstract}
Objectively, this study was conducted to analyze the impact of the Coastal Community Development Project in collaboration with the International Fund for Agriculture Development (CCDP-IFAD) on education, business experience, involvement of women and men in the program, economic improvement of recipient communities, and program effectiveness. In improving the welfare of society. Literature studies and field studies carried out data collection techniques through interviews, observations, and documentation. Using a stratified random sampling method, samples were taken with 88 respondents consisting of 34 processors, eight farmers, 23 marketers, and 23 fishers. The results showed that the coastal communities who were assisted by the CCDP-IFAD program had a sufficient level of education and experience so that they were able to receive the program well. In addition, the level of women's involvement in the project of $50 \%$ has met the project requirements that require the involvement of women at $20 \%$. The results also show that the CCDP-IFAD program is effective for the processing group with a value of 2.5 or $63.12 \%$, the cultivation group 2.1 or $54.86 \%$, and less effective for the marketer group of 1.98 or $45.75 \%$, and the fishing group with a value of 1.93 or $40.36 \%$.
\end{abstract}

\section{Keywords:}

Coastal Society, CCDP-IFAD

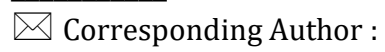

E-mail address: zulkiflijamid99@gmail.com (Jl. Monginsidi, Sarae, Rasanae Makassar, Indonesia)

“Received 08 December 2021, Accepted 14 December 2021, Published 14 January 2021” 


\section{Introduction}

The coastal area is an area that has diverse resources both in type and potential and is a unitary space between land and sea (Setiawan, 2010). Various potentials of abundant marine wealth make the sea and coast a paradise for every sailor and fisher to live in the area to seek life in sustaining life and business development. However, the reality is that fishers who inhabit the coast of $22 \%$ of Indonesia's population become a backward and marginalized group (Ginting, et al., 2015).

This research was conducted because the types and business activities strongly influence the people who live in coastal areas in the fishery sector, such as capture fisheries, aquaculture, fishpond business, fishery product processing, and fish marketing business. The thing that is the biggest concern of the government at this time is that the life of coastal communities is very worrying in terms of the economy. Most of them live in the poverty line (poor line) and are marginalized, with limited connecting infrastructure and various supporting facilities for business activities.

Poverty alleviation can be done by making efforts to manage community-based natural resources in an integrated manner by involving the government, the community, and all relevant stakeholders to reduce conflicts of interest. These efforts can be carried out by planning, monitoring, and evaluating activities in coastal areas and small islands towards the potential of each region. Utilization of any coastal and marine resources also needs to be carried out by taking sustainable management and utilization (Nasution et al., 2007).

The Ministry of Maritime Affairs and Fisheries (KKP) in 2012 showed concern for the welfare of coastal communities by launching the Coastal Community Development Project (PPMP), which is a collaboration between the Indonesian government through the Ministry of Maritime Affairs and Fisheries with the International Fund for Agriculture Development (IFAD) to eradicate poverty, absorb labor, encourage economic growth and for sustainable sustainability (pro-poor, pro-job, pro-growth, and pro-sustainability). The CCDP-IFAD project is expected to target households that can implement profitable marine-based economic activities without causing adverse effects on marine resources, expand economic opportunities in the project district for sustainable, marketbased, small-scale fisheries/marine businesses, and the project is managed efficiently and transparently to benefit the project's target households and the community. 
One form of activity that is part of the CCDP-IFAD project is community empowerment activity by raising the passion and ability of the community to participate in project implementation by developing an entrepreneurial spirit supported by various business equipment assistance facilities and marketing assistance for processed products made by the community.

One of the areas targeted for CCDP-IFAD activities is the City of Parepare. The city of Parepare was chosen because of the potential for good coastal and marine areas with a large and dense number of residents living in coastal areas. In general, they have the same problems as other coastal areas. In terms of knowledge, mastery of technology, and awareness in carrying out coastal area management is still very lacking. People who live in the coastal area of Parepare are pretty vulnerable to poverty and cause economic pressure. Therefore, one of the efforts to overcome these problems is through improving welfare through community empowerment activities in the CCDP-IFAD project in providing comprehensive guidance and assistance in improving community welfare through economic activities, human resource development, and institutional strengthening. Based on the description above, a study was conducted that examined the "Impact of Coastal Community Empowerment through the Coastal Community Development ProjectInternational Fund For Agriculture (CCDP-IFAD) in Parepare City.

\section{Literature Review}

Poverty is a problem that is always actual so that the study of the concept of poverty is a positive effort to produce suitable approaches and strategies in tackling the crucial problems faced today. The dimension of poverty is closely related to the economic, political, and social psychological aspects. The economic dimension of poverty is defined as a lack of resources that can improve the welfare of a group of people, both financially and all types of wealth, that can improve people's welfare (Ellies, 1994). Idris et al. (2007) explain that poverty is one of the causes of environmental degradation. Economic pressure tends to make people exploit resources excessively without paying attention to the sustainability of existing resources.

The magnitude of the poverty rate poses a relatively high risk, and if not addressed immediately, it will lead to various negative behaviors and can form a vicious cycle. Anger will be more easily provoked, become unproductive, irritable, dark eyes, anarchic and hopeless. Another significant 
impact that can arise from these problems is the birth of a weak, less intelligent, and unproductive next generation (Idris et al., 2007).

The concept of empowerment initially emerged as a critique of the development paradigm that places the state to domino in carrying out development. The central position of the state is seen from the planning stage to the implementation and evaluation stages. The concept of empowerment assumes that development will run smoothly if the community is given the opportunity or has the right to manage existing resources for the benefit of the community itself. They are empowering people who cannot escape from the trap of poverty and underdevelopment in their current condition to increase their dignity. In other words, empowering increases the ability and increases the community's independence (Rahim et al., 2014).

Empowerment emerged as a strategy in the paradigm of people-centered development. This concept arises from two words, namely, between failure and hope. The failure in question is the failure of the economic development model in tackling poverty and a sustainable environment. At the same time, hope arises because of development alternatives prioritizing democratic values, gender equality, equality between generations, and adequate economic growth (Rahim et al., 2014). Empowerment and participation are strategies with great potential to improve economic, social, and cultural transformation. This process, in the end, will be able to create a more peoplecentered development. For example, one international agency, the World Bank, believes that community participation in third world countries is an effective means to reach the poorest communities through efforts to generate enthusiasm for life to help themselves (Hikmat 2006).

The Ministry of Maritime Affairs and Fisheries (KKP) is concerned for the welfare of its coastal communities who permanently live in poverty, so in 2013 a collaborative project was launched between the Indonesian government and the International Fund for Agriculture Development (IFAD). The project is implemented in 12 districts/cities, 180 coastal villages located in eastern Indonesia, namely: Merauke (Papua), Yapen (West Papua), Ternate (North Maluku), Ambon and Southeast Maluku (Maluku), Kupang (NTT), West Lombok (NTB), Bitung (North Sulawesi), North Gorongtalo (Gorongtalo), Parepare and Makassar (South Sulawesi), and Kubu Raya (West Kalimantan) with Bali as a learning center (Ginting et al, 2015). 
The CCDP-IFAD project activities are implemented at the central level, where project activities are managed by the PMO (Project Management Office), which has overall responsibility for running and coordinating the course of this project. Some of the activities carried out are carrying out accounting, reporting, monitoring, and evaluation activities and building human resource and institutional capacity for project partners in improving project performance nationally. The PMO is led by a project director, supported by a full-time executive secretary and technical and administrative management staff (KKP, 2012).

The implementation of CCDP-IFAD project activities at the village level is carried out by the village's willingness to participate in the project, facilitating village level meetings, and providing support, forming a Village Project Working Group (PWG) (KKP, 2013).

The background of implementing the CCDP-IFAD project is to reduce the level of poverty in the community, especially coastal communities. Therefore, several community groups were formed to become project partners with the hope that the direct assistance provided would improve the living standards of coastal communities in terms of a thriving, sustainable and market-based economy.

The people of Parepare City who live in coastal areas still face various social problems, and some still live on the poverty line. The number of people who live in coastal areas is quite large and dense due to the ease of accessing marine resources in the sense of being fishermen, easy access to transportation, terrain that is easier to reach is an inseparable part. Talking about coastal areas, what comes to mind is white sand, clean water, and beautiful nature, but the dense population living inversely causes this; traditional markets that do not pay attention to the environment make the area dirty and dirty, especially when being in a fish market right in the coastal area, the fishy smell, black mud, and smelly water are in various places. This is a reflection of how the living conditions of the people living in the area are.

Various kinds of coastal area management problems are also an inseparable part of the shared community understanding of the values of coastal resources as a whole. Coastal communities tend to be consumptive without paying attention to the sustainability of any existing ecosystems. This then makes people live below the poverty line. 


\section{Method, Data, and Analysis}

The research was carried out in the Coastal Area of Parepare City, precisely in nine villages, namely Watang Soreang, Lakes, Pisang Village, Baru Village, Labukkang, Cappa Galtung, Tiro Some, Sumpang Minangae, and Lumpur, which the CCDP-IFAD project has assisted since 20132015. In this study, we use a survey method collected in the study, namely primary data and secondary quantitative and qualitative data (Arikunto, 2010). The types of data in detail can be seen in table 1.

Table 1. Jenis, spesifikasi data, sumber data dan teknik pengumpulan data

\begin{tabular}{|c|c|c|}
\hline Data type & Sumber data & Informasi Data \\
\hline Primary data & Interview & $\begin{array}{l}\text { - Characteristics of respondents } \\
\text { - Respondent's income and capital } \\
\text { - Respondent's response }\end{array}$ \\
\hline \multirow[t]{7}{*}{ Data Sekunder } & $\begin{array}{l}\text { - Ministry of Marine Affairs and } \\
\text { Fisheries of the Republic of } \\
\text { Indonesia }\end{array}$ & $\begin{array}{ll}\text { - } & \text { CCDP-IFAD project funding } \\
- & \text { CCDP-IFAD } \\
& \text { structure } \\
\text { - } & \text { CCDP-IFAD general guidelines }\end{array}$ \\
\hline & $\begin{array}{l}\text { - Central Bureau of Statistics of } \\
\text { the City of Parepare }\end{array}$ & $\begin{array}{l}\text { General condition of West } \\
\text { Bacukiki District }\end{array}$ \\
\hline & $\begin{array}{l}\text { - CCDP-IFAD Blue Pearl } \\
\text { Cooperative }\end{array}$ & $\begin{array}{ll}\text { - } & \begin{array}{l}\text { Cooperative } \\
\text { structure }\end{array}\end{array}$ \\
\hline & & $\begin{array}{l}\text { - Number of community groups } \\
\text { involved in the project and } \\
\text { joining the cooperative }\end{array}$ \\
\hline & 1. Parepare City PKPK Service & $\begin{array}{l}\text { - Number of people receiving } \\
\text { government assistance. }\end{array}$ \\
\hline & 2. Food Security Agency & - Implementation of counseling \\
\hline & 3. LSI, IPB and others & - Previous research \\
\hline
\end{tabular}

The expected impact in community empowerment activities is an increase in income for coastal communities through business activities carried out by each group member so that the implementation of empowerment activities can be achieved. The research framework can be seen in Figure 1. 


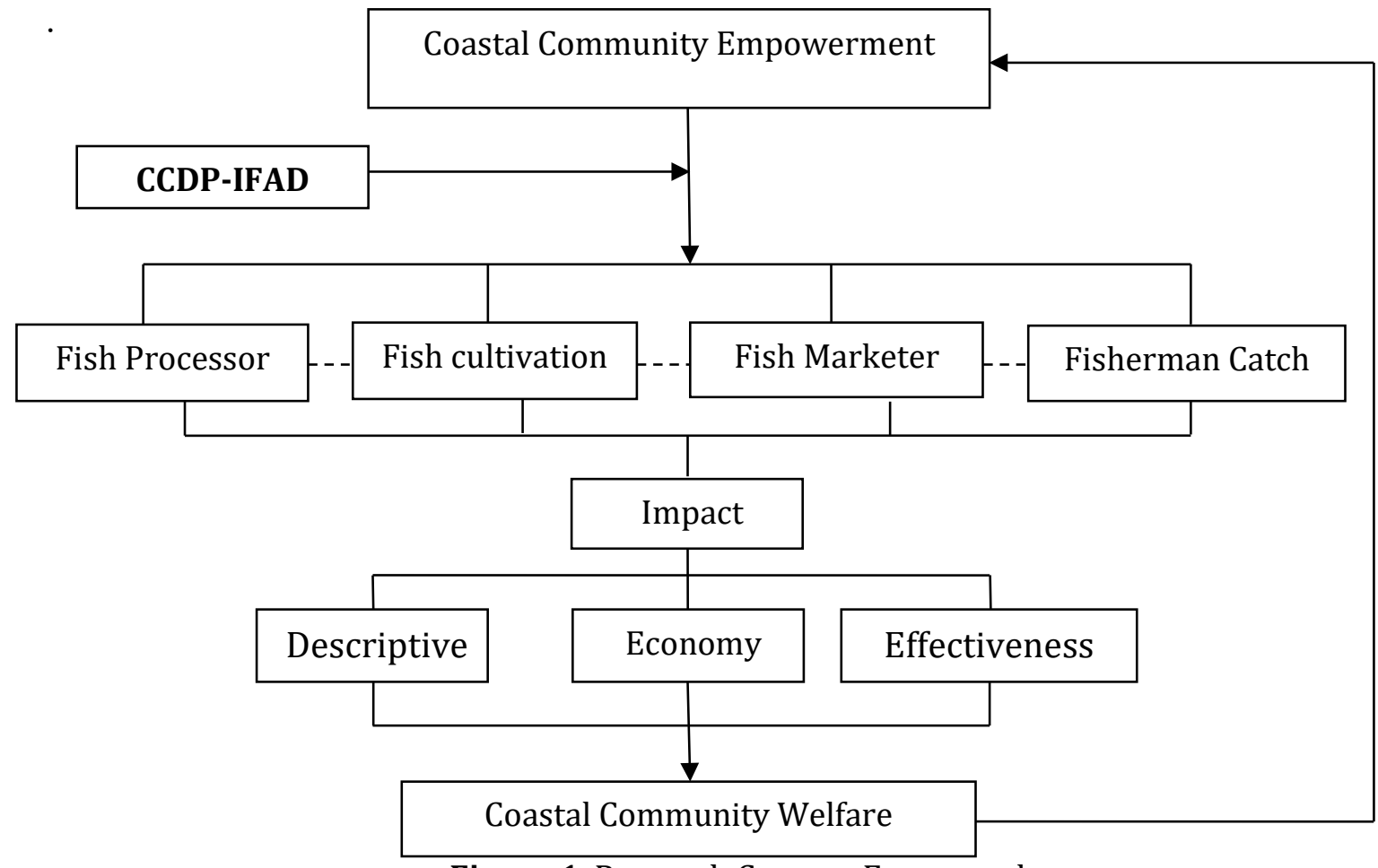

Figure 1. Research Concept Framework

The total population in the CCDP-IFAD project from 2013-2015 was 788 people consisting of members of fish farming groups, processors, marketers, and capture fishers. The sampling of respondents was done by stratified random sampling method. The population is grouped by type of beneficiary business. The Slovin formula calculated the total sample in Sugiyono 2011 with the number of respondents taken as many as 88 people consisting of 23 fishing fishers, 34 fish processors, 23 marketers, and eight cultivation people.

\section{Result and Discussion}

The amount of project funds for each region is different and becomes one of the assessment points supporting the successful implementation of project programs. The city of Parepare is one area that is considered to have a reasonably low level of absorption of funds-especially in 2015 with the percentage of absorption only at $67.6 \%$ compared to 2014 at $89.5 \%$, in 2013 at $91 \%$ and in 2016 at 98\%. The absorption rate of project implementation funds from the beginning of 20132016 in Parepare City can be seen in table 2.

Table 2. Parepare City Fund Absorption Rate 2013-2016 


\begin{tabular}{cccc}
\hline \hline Year & Amount of funds (Rp) & Realization (Rp) & Percentage \% \\
\hline 2013 & $2,973,171,000$ & $2,704,109,645$ & 91.0 \\
2014 & $5,277,332,000$ & $4,722,084,100$ & 89.5 \\
2015 & $5,800,000,000$ & $3,918,401,906$ & 67.6 \\
2016 & $6,500,000,000$ & $6,368,386,240$ & 98.0 \\
\hline Total & $\mathbf{2 0 , 5 5 0 , 5 0 3 , 0 0 0}$ & $\mathbf{1 7 , 7 1 2 , 9 8 1 , 8 9 1}$ & 86.2 \\
\hline \hline
\end{tabular}

Department of Agriculture, Maritime Affairs and Fisheries, 2016

The low level of absorption of funds due to financial regulations that are constantly changing and the manager's hesitation in using and distributing funds for each activity is one of the problems in project implementation in the City of Parepare. Activity funds are also widely used at the end of the year, which is not by the existing schedule. These all then become weaknesses and problems that occur not only in the city of Parepare. So that more integrated project management and firmness of project implementation rules at the beginning of the year are critical to be considered and considered so that activities can be carried out correctly and by the rules.

Figure 1. Percentage of Increase and Decrease in Operating Income

\section{$\%$ Income increase and decrease}

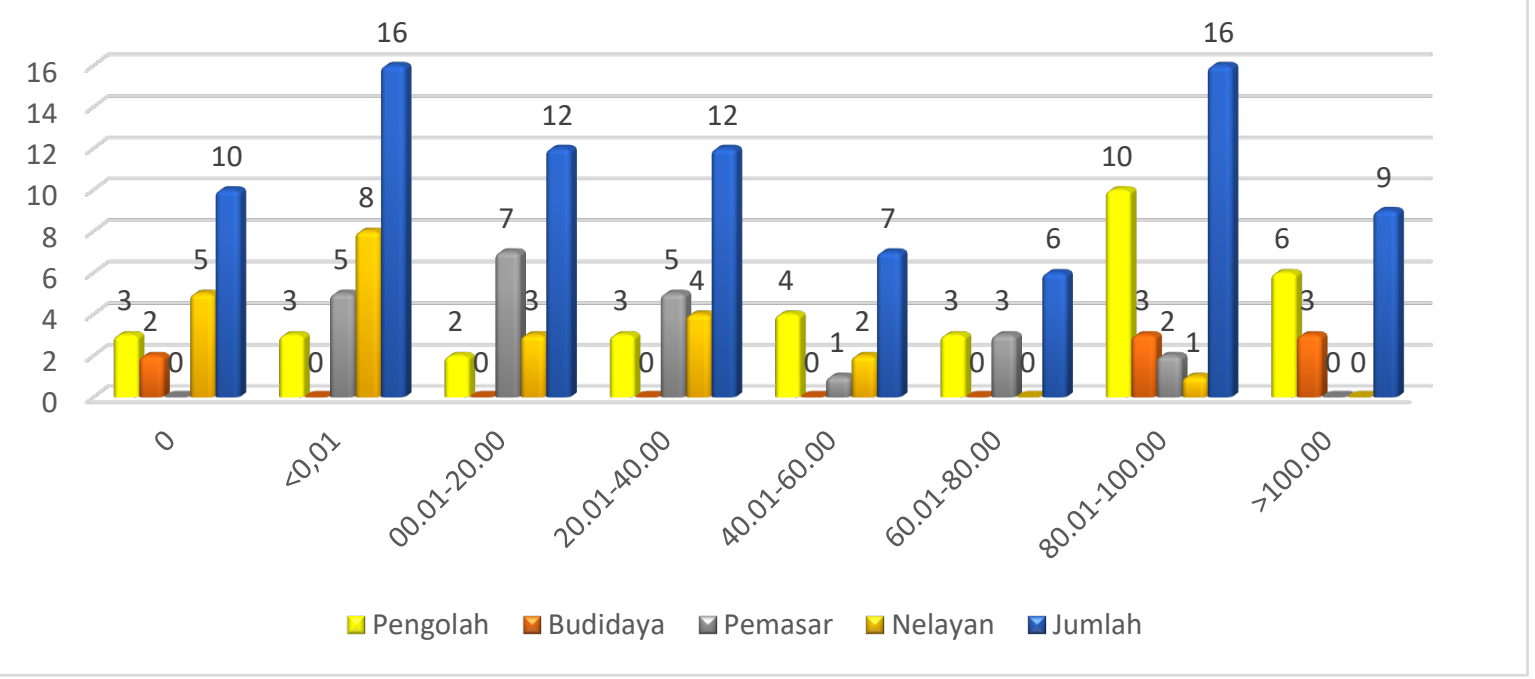

The results of the economic analysis seen from the profit approach showed that there was an increase in income as much as $>100 \%$ as many as nine people, $80.01-100 \%$ as many as 16 people, $60.01-80.00 \%$ as many as six people, $40.01-60.00 \%$ as many as seven people. Twelve people, 
$20.01-40.00 \%$ as many as 12 people, and $10.01-20.00 \%$ as many as 12 people showed no increase or decrease as many as 16 people and as many as ten stops/vacuum. A significant increase in income from $80.01-100 \%$ and $>100 \%$ was seen in the processing group, namely 16 people. This processing group was a coastal housewife who previously did not have a job, and some only processed based on orders. After joining the group and being assisted by IFAD, they become routinely productive and generate their income. The increase in the income of homemakers shows their independence in carrying out their business. In addition, there is a processing group dominated by single mothers who make this business their primary source of livelihood in financing their children every day, starting from clothing, food, and children's education.

In the marketer and cultivation group, income levels are pretty diverse and fluctuate, followed by the availability of raw materials and market demand. Until now, both types of business are still quite profitable and are widely cultivated in general, so there are no problems that are crucial in group business. On the other hand, there are five fisherman members, three processors, and two cultivation in the fishermen group. They quit or change professions to become laborers, car drivers, and others. The vacuum for some fishermen is because they are only part-time fishermen or sick and cannot work hard, so they focus more on other businesses. In addition, fishermen's businesses are considered unable to meet the needs of life, and catches are only adequate in certain seasons.

Another thing that cannot be denied is the low increase or decrease in business income, especially for fishers in general, also due to the limited capacity of the boats and fishing gear used so that the catchment area is also limited. The sea area of Parepare city, which is only $11.6 \mathrm{~km}$, does not allow fishers to get a large number of fish catches, so they have to look for fish in the Pinrang, Barru, and other nearby areas, which of course require adequate boat capacity and fishing gear as well as supported by resource capabilities. Fisherman himself. The income level of fishers is also influenced by the engine's ability, the capacity of the boat, and the type of fishing gear used. So some get a small profit of $<0.01-40 \%$ and a relatively large profit of $40 \%-80 \%$ of the profit from the catch.

Ginting et al. (2017) explained that although income was increased for the fishermen group, it was not directly proportional to their consumptive lifestyle. They do not think about making long-term 
investments. Moreover, this can be seen from the low level of education in the fishermen group, who on average, only attend elementary school. This happens because a reasonably high income tempts them. In addition, Idris (2007) also explains that fishermen's catches are not worth the costs, given the increase in fuel prices and other raw material prices, which makes their lives worse.

In contrast to the processing group, the reason for their stop was due to an error at the beginning of the aid distribution process, which eventually led to misunderstandings within the group so that they chose to do their production due to their inability to work together in groups and some even chose to stop. Groups that experience problem like this are often found in groups formed in 2013-2014. However, in 2015 and above, the group has begun to be more supervised and accompanied by assistant staff and the related agencies, namely the Agriculture, Forestry, Fisheries, and Marine services, in this case, the PIU (Project Implementation Unit) to minimize the same thing happening.

In the cultivation group, two people are not producing because they are considered to have failed in not being able to carry out cultivation activities properly. A disease attack usually causes crop failure. The results of observations and interviews conducted by groups that are no longer productive are the seaweed cultivation group. Field results show that they have stopped cultivating seaweed because they often experience crop failure. Over time, the assistance provided was not utilized optimally or converted into a means of catching fish. Unlike the case with the catfish cultivation group, it was pretty good until 2015-2016; the catfish cultivation group was then in demand and developed quite rapidly. Several group members have succeeded in pioneering the cultivation business as the primary source of income, namely the Joint Development Business group in Lumpue Village. This can then attract the government's attention to pay more attention to this field as an alternative livelihood, especially for fishing communities. Meanwhile, in the marketer group, the profits obtained are pretty varied, and this is highly dependent on the number of catches of fishers and the season of fish. If the number of fish is abundant, the price of fish becomes cheap, which sometimes causes losses, and vice versa if the number of fish is small, the price of fish rises. The marketer group consistently markets fish in the market or sells around Parepare. Some even market it to blood ping or sidrap by using a motorbike 
or car by selling in the local market or around. The profit obtained depends on the size and number of fish sold and the location of the sale.

The problems faced, especially in groups of fishermen, then became the concern of the local government, that the distribution of future assistance will only be given to people who are struggling in this field and do not work as temporary fishermen who only go to sea in certain seasons and pay close attention and analyze the governance system. the distribution process so that the assistance provided is correct and on target

\section{Effectiveness of CCDP-IFAD Project Implementation}

The CCDP-IFAD assisted fish processing group in Parepare City from 2013-2016 reached 39 groups consisting of 8-10 people per group. The superior product is shredded tuna. In addition to shredded, other preparations made are fish balls, siolam, tatum, kerubak, fishbone sticks, milkfish pull-out thorns, fish snacks, crispy losa, dry losa, amplang, nuggets, otak-otak, shredded bread, tuna beans. The type of assistance provided is adjusted to the type of product processed by each group.

Based on the results of the analysis of project effectiveness for the processing group, it shows effective results with a value of 2.5. The percentage of effectiveness looks effective $6.12 \%$, less effective $22.67 \%$, very effective $9.32 \%$, and not effective $4.89 \%$.

Table 3. CCDP-IFAD Project Effectiveness on Fish Processing Group

\begin{tabular}{|c|c|c|c|c|}
\hline Effectiveness Level & Weight & Frequency & Score & $\begin{array}{c}\text { Percentage } \\
\text { (\%) }\end{array}$ \\
\hline Very effective & 4 & 30 & 120 & 9.32 \\
\hline Effective & 3 & 271 & 813 & 63.12 \\
\hline Normal & 2 & 146 & 292 & 22.67 \\
\hline Ineffective & 1 & 63 & 63 & 4.89 \\
\hline Total & & 510 & 1.288 & \multirow[t]{2}{*}{100} \\
\hline Average & & & 2.5 & \\
\hline
\end{tabular}

Project effectiveness in the processing group is also shown by adding ownership assets such as spinners, fryers, scales, buckets, pans, trays, containers, and knives. Ginting (2015) explained that the results of the RIMS. (Result \& Impact Management System) in 2015 showed the same result that there was a double increase in assets compared to the previous year, and this shows that processed fish can develop and compete with various other preparations besides fish. The 
packaging and design used by the processing group from the beginning of the project until 2016 underwent a significant change.

Types of processed that are pretty developed are processed Fish Shredded, Siomay, Fish Snack, and Fish Meatballs.

The CCDP-IFAD target group of Parepare City that is included in the success story is the Kedai Pesisir shredded tuna processing business group which currently produces 700-800 kg per month compared to the initial project, which only produced $5 \mathrm{~kg}$ (Ibrahim, 2016) in Gema Pesisir Magazine which published in the July 2016 edition. Thanks to the expertise and tenacity, the group survived and competed with many shredded entrepreneurs who already have pretty well-known names, such as Abon Lela Mandiri, Abon Dinda, and others. The rambutan group that makes fish lemper has increased quite rapidly. In 2015, the group only served orders from stalls and sold directly, but production increased significantly after joining the CCDP-IFAD project 2015 . Products began to be known through promotions at the service level, exhibitions, and the introduction of food and beverage business relationships facilitated by component II as a supporter of the group product market supply chain. The increase in income drastically increased, and the group began to try to make new preparations as an innovation to increase business. In addition to these two types of products, the Irrenuang group, which produces siolam and tuna tofu, is also not less competitive. Products are sold in frozen form and ready-to-eat form as an addition to the selling value of the product. This group has been able to open its dining stand from the sales, which shows its success in managing its business.

The product marketing approach is also carried out intensively with a mentoring model. Various strategies were developed during the mentoring process to involve buyers, partners, producers, and other business groups. Marketing intervention is an essential factor in the processing group's success in increasing the processing group's income. Zawawi (2016) explains that three main steps can be taken in a marketing strategy, namely 1) covering two stages, one identifying market opportunities, including district/city market validation and the comparative advantage of business groups, both production defects, and joint action plans. 2) identify and analyze the condition of only commodities and their derivatives, including the production process, product quality and quantity, availability of raw materials and packaging, 3) draft marketing intervention strategies such as product, distribution, promotion, and pricing strategies. Tuwo (2011) also 
explained that there needs to be support and market access to develop products produced by bringing the community closer to large companies or exporters of fishery commodities. Marketing support in the IFAD project, especially Component II, is expected to support and guarantee the product supply chain by collaborating with small and large-scale food and beverage retail businesses.

Fish cultivation groups in 9 kelurahan assisted by CCDP-IFAD from 2013-2016 have small groups. The cultivation group only consisted of 5 cultivation groups. The results of the analysis of the effectiveness of the fish farming group were considered effective, with an average score of 2.1. The percentage level of project effectiveness can be seen in table 5 , which shows that this project is $54.86 \%$ effective, $33.46 \%$ less effective, and $11.67 \%$ ineffective.

Table 4. CCDP-IFAD Project Effectiveness on Fish Farming Group

\begin{tabular}{|c|c|c|c|c|}
\hline Effectiveness Level & Weight & Frequency & Score & $\begin{array}{c}\text { Percentage } \\
(\%)\end{array}$ \\
\hline Very effective & 4 & 0 & 0 & 0.00 \\
\hline Effective & 3 & 47 & 141 & 54.86 \\
\hline Normal & 2 & 43 & 86 & 33.46 \\
\hline Ineffective & 1 & 30 & 30 & 11.67 \\
\hline Total & & 120 & 257 & \multirow{2}{*}{100} \\
\hline Average & & & 2.1 & \\
\hline
\end{tabular}

The productivity of aquaculture groups has increased from the beginning of the project until 2016, previously using only tarpaulin ponds. They are now able to make cement ponds with the assistance provided by CCDP-IFAD project activities. This provides added value for the cultivation group as a facility that can be used for a longer time than tarpaulin ponds.

The type of fish that the CCDP-IFAD target group cultivates in Parepare is catfish. Based on the results of field research and interviews conducted, why then many people choose catfish because the technology used is relatively easy, cheap, and quickly mastered by the community; fish seeds are elementary to obtain, 3) maintenance is not difficult and easy to adapt to the water quality environment which is quite extreme in other types of fish. The maintenance period is relatively short, only 3-4 months, and produces fish with a size of 4-6 fish $/ \mathrm{kg}$. The catfish cultivation business group that is included in the Success Story of IFAD Parepare City is the Joint Development Business group. Members of the group consisted of women (women) who at first just for fun doing 
cultivation activities. In 2014 it became part of the project and experienced a relatively rapid increase in business. This is inseparable from the assistance provided in procuring permanent ponds, seeds, and feed as additional group efforts. In addition, training such as technical guidance, learning to share, and mentoring are supporting factors for group success.

Table 5. Efektivitas Proyek CCDP-IFAD pada Kelompok Pemasar Ikan

\begin{tabular}{|c|c|c|c|c|}
\hline Effectiveness Level & Weight & Frequency & Score & $\begin{array}{c}\text { Percentage } \\
(\%)\end{array}$ \\
\hline Very effective & 4 & 3 & 12 & 1.76 \\
\hline Effective & 3 & 104 & 312 & 45.75 \\
\hline Normal & 2 & 120 & 240 & 35.19 \\
\hline Ineffective & 1 & 118 & 118 & 17.30 \\
\hline Total & & 345 & 682 & \multirow{2}{*}{100} \\
\hline Average & & & 1.98 & \\
\hline
\end{tabular}

The fish marketers group in Parepare that is part of the CCDP-IFAD project consists of 25 groups. The fish marketing model carried out by each group member is different. Some sell bicycles, carts, motorbikes, selling in the market, and processing raw fish into ready-to-eat, and then selling them. The type of assistance provided by the CCDP-IFAD project is tailored to the needs of each person in the marketer group.

The results of the analysis of project effects on the fish marketer group are considered less effective, with an average value equal to 1.98 . The percentage of project productivity can be seen as effective $45.75 \%$, less effective $35.19 \%$, ineffective $17.30 \%$, and very effective $1.76 \%$. The value is considered quite vulnerable because it is likely that there will be a decrease in project effectiveness as the project implementation time increases. The assistance provided will decrease and even be damaged so that there need to be maintenance costs or additional assets, which must come from the group. So the group needs to think about allocating funds for maintenance costs or additional business assets. The results of the field research show that some of the group aid items were damaged, and some did not take full advantage of the aid items. One respondent explained that some goods could not be utilized optimally because the production capacity is not much, so the goods provided do not function (only stored). This was confirmed to the Department of Agriculture, Maritime Affairs, and Fisheries, in this case, the PIU of the City of Parepare, explaining that the assistance was given based on the proposals given by each group member through the TPD. So that when an error occurs or the item is not utilized, it becomes the group's responsibility. 
So that in the following aid proposal, the group is expected to really have to pay attention to the real needs of the business and not just propose.

Table 6. CCDP-IFAD Project Effectiveness on Capture Fishermen Group

\begin{tabular}{|c|c|c|c|c|}
\hline Effectiveness Level & Weight & Frequency & Score & $\begin{array}{c}\text { Percentage } \\
(\%)\end{array}$ \\
\hline Very effective & 4 & 0 & 0 & 0.00 \\
\hline Effective & 3 & 90 & 270 & 40.36 \\
\hline Normal & 2 & 143 & 286 & 42.75 \\
\hline Ineffective & 1 & 113 & 113 & 16.89 \\
\hline Total & & 346 & 669 & \multirow{2}{*}{100} \\
\hline Average & & & 1.93 & \\
\hline
\end{tabular}

The CCDP-IFAD project assists fishing groups and is part of the program. The type of assistance is provided based on the level of need of each group member. Some examples of the assistance that has been provided are painting engines, boats, boat repairs, and fishing gear. From the assistance that has been provided from the CCDP-IFAD project, it is hoped that it will be effective in increasing the number of catches from fishers. Based on the results of research conducted in the field, the effectiveness of the CCDP-IFAD project that has been implemented over the last four years from the results of direct interviews, no one stated that this project was very effective, but $40.36 \%$ effective, $42.27 \%$ less effective and $16.89 \%$ ineffective. The average result of the assessment of each answer given by the respondent was declared less effective, with an average value of 1.93. This shows that the assistance provided by the government through the CCDP-IFAD program is less effective in increasing the number of catches and income of project recipient communities.

\section{Conclusion and Suggestion}

The results of the analysis of this study indicate that the CCDP-IFAD target group of Parepre City has a fairly good level of education, so that the ability to accept and implement projects is maximal. In addition, the involvement of women in the project by $50 \%$ shows that the number of women's involvement in the project is $20 \%$. The coastal management process in the project provides considerable benefits by involving all relevant stakeholders in maintaining coastal sustainability. The CCDP-IFAD project is considered effective for the processing group with a score of 2.5 (63.12\%) and aquaculture $2.1(54.86 \%)$ while less effective for the marketer group with a score of $1.98(45.75 \%)$ and fishermen1, 93 (42.75\%). 
The community's indifference to coastal resources leads to overexploitation which tends to overfish and is not environmentally friendly and ultimately impacts the lack of fish resources. Observation results show that many fishers switch professions because the income from fishing is considered insufficient and cannot meet the necessities of life. In addition, other problems are the limited marine resources that can be exploited due to the limitations of the fishermen themselves, and most of the fishermen are of unproductive age, so they rarely go fishing, and the fishermen's lifestyle, which is considered consumptive, causes no awareness to save. Therefore, they stop fishing and become laborers, car drivers, or open businesses. Taking into account all the existing problems, the government needs to take a role by not only assisting, but education, and an understanding of life awareness needs to be implemented, which of course can be done with counseling to improve human resources, cultural education, or lifestyle as well as household financial management. Improving community welfare through empowerment projects requires a persuasive approach and character education, especially for fishers, to be implemented optimally.

\section{Reference}

Abibu, U. (2007). Analisis Penanggulangan Kemiskinan Melalui Proyek Pengembnagan Kecamatan (PPK) di Kabupaten Konawe. Tesis. Proyek Studi Ilmu Ekonomi dan Studi Pembangunan Proyek Pascasarjana Universitas Haluoleo. Kendari.

Arikunto, S. 2010. Prosedur Penelitian Suatu Pendekatan Praktek. Jakarta : Rhineka Cipta.

Badan Pusat Statistik. 2014. Kota Parepare dalam Angka Tahun 2014. Kota Parepare : BPS Kota Parepare

Badan Pusat Statistik. 2014. Kota Parepare dalam Angka Tahun 2015. Kota Parepare : BPS Kota Parepare

Badan Pusat Statistik. 2014. Kota Parepare dalam Angka Tahun 2016. Kota Parepare : BPS Kota Parepare

Cook, S., \& Macaulay, S. (1997). Practical steps to empowered complaint management. Managing Service Quality: An International Journal, 7(1), 39-42.

Chriswardani S, 2009. Memahami Kemiskinan Secara Multidimensional. http://www.jmpkonline.net/Volume_8/Vol_08_No_03_2005.pdf.

Craig, G. and Mayo, M. (eds) (1995) Community Empowerment. A Reader in Participation and Development. London: Zed Books. Pp. 1-11.

Dahuri, 2011. Membangun Perikanan Berkelanjutan. Wordpress Dahuri.

Dinas Pertanian, Kehutanan, Kelautan dan Perikanan. 2016. Data Pengelolaan Keuangan Proyek CCDP-IFAD. Kota Parepare : PIU Kota Parepare. 
Ellies,S.1994. The Dimension of Proverty. Jakarta: Kumarian Press

Gintinng, S.P., Natasukarya A., Mashari H., Suahrso R., Setyawan I., Zaini H., Koesindriyani I., Ruslan B. M., Styawati, T.A., Sutenti., Fitrianto I. 2015. Annual Autocome Survey. Direktorat Jendral Pengelolaan Ruang Laut Kementerian Kelautan dan Perikanan-International Fund For Agriculture Development (IFAD):PMO CCDP (Project Management Offince-Coastal CommuntyDevelopment Project.

Ginting, S.P., Bustomi H., Laturharheri, Rahman, Setyawan I, Zaini H, Koesindriyani I, Ruslan BM., Setyawati A, Sutenti dan Fitrianto I, 2015. Result \& Impact Management System (RIMS). Jakarta : Direktorat Jendral Pengelolaan Ruang Laut Kementerian Kelautan dan Perikanan.

Hermanto F. 1989. Ilmu Usaha Tani. Jakarta: PT. Penebar Swadaya.

Hikmat A. 2006.Strategi Pemberdayaan Masyarakat. Bandung: Humaniora Utama Press. $240 \mathrm{hlm}$.

Huda, N. (2005). Dampak Pemberian Kredit Mikro terhadap pendapatan Masyarakat perdesaan melalui Lembaga Simpan Pinjam Berbasis Masyarakat dari Proyek Pemberdayan Masyarakat (CERD) di Kecamatan Aluh-Aluh Kabupaten Banjar. Tesis Proyek Studi Ilmu Ekonomi Proyek Pascasarjana Universitas Gadjah Mada Yogyakarta.

Husein, F. 2013. Analisis Efektivitas Pemberdayaan Masyarakat ( Studi Kasus :Persepsi Masyarakat Miskin Terhadap Proyek Nasional Pemberdayaan Masyarakat Mandiri Pedesaan di Kecamatan Tegalampel Kabupaten Bondowoso). Jember : Universitas Jember.

Idris, I, Ginting, S.P., Budiman. 2007. Membangun Raksasa Ekonomi sebagai Kajian terhadap Perundang-undangan Wilayah Pesisir dan Pulau-pulau Kecil. Bogor : Buku Ilmiah Populer.

Ibrahim, A. 2016. Gemas Pesisir Gerakan Membangun Masyarakat Pesisir Coastal Community Development Project-International Fund For Agriculture Development, Kementerian Kelautan dan Perikanan. Edisi Juli 2016. Jakarta : KKP.

Kartasasmita, G. (1996). Pembangunan Untuk Rakyat: Memadukan Pertumbuhan dan Pemerataan. Jakarta: Pustaka Cidesindo.

Kementerian Kelautan dan Perikanan dan Coremap II. 2011. Kabar Bahari Peduli Laut untuk Kesejahteraan Edisi I Desember 2011. Jakarta Selatan : PT Gemini Mitra Gemilang.

Kementerian Kelautan dan Perikanan. 2012. Dokumen Proyek Pembangunan Masyarakat Pesisir : Lampiran Panduan Pelaksanan Proyek. Direktorat Pemberdayaan Masyarakat Pesisir dan Pengembangan Usaha, Direktorat Jenderal Kelautan, Pesisir dan Pulau-pulau Kecil, Kementerian Kelautan dan Perikanan Bekerjasama dengan International Fund For Agricultural Development.

Kementerian kelautan dan perikanan. 2013. Pedoman Teknis Proyek Pembangunan Masyarakat Pesisir. Direktorat Jendral Kelautan, pesisir dan Pulau-pulau kecil. No.03/PER-DJKP3K/2013.

Laksana, Angga Duwan Putra. 2012. Analisis Faktor Yang Mempengaruhi Kemiskinan Di Desa Mojomulyo Kecamatan Puger Kabupaten Jember. Skripsi. UNEJ.

McArdle, J. (1989), “Community Development Tools of Trade”. Community Quar-terly Journal 16: 47-54 p 
Nasution Z, Sastrawidjaja, Hartono, Mursidin, Priyatna. 2007. Sosial Budaya Masyarakat Nelayan Konsep dan Indikator Pemberdayaan. Jakarta: Balai Besar Riset Sosial Ekonomi Kelautan dan Perikanan. $147 \mathrm{hlm}$.

Nikijuluw. 2003. Aspek Sosial Ekonomi Masyarakat Pesisir dan Strategi Pemberdayaan Mereka dalam Konteks PengelolAAN Summberdaya Pesisir Secara Terpadu. In : Koleksi Dokumen Proyek Pesisir 1997-20013 (Knight, M dan S. Tighe, editor). Coastal Resources Center University of Rhode Island, Narraganset, Rhonde Island, USA.

Rahim, M., Tahir M., Rumbia WA. 2014. Model Pemberdayaan di Wilayah Pesisir dalam Menanggulangi Kemiskinan di Kabupaten Buton. Jurnal The Winners, Vol.15 no 1, Maret 2014. Sulawesi Tenggara. Universitas Haluoleo.

Riyadi, P.H. 2006. Analisis Kebijakan Keamanan Pangan Produk Hasil Perikanan di Pantura Jawa Tengah dan DIY Proyek Studi Magister Manajemen Sumberdaya Pantai. Semarang : Proyek Pascaasarjana Universitas Ponegoro.

Setiawan, F. 2010. Raja Ampat. Fakultas Perikanan dan Ilmu Kelautan Universitas Padjajaran.

Siregar, Hermanto, Dwi Wahyuni, dan Nur Azam Achsani. 2007. Dampak Pertumbuhan Ekonomi terhadap Penurunan Jumlah Penduduk Miskin. Makalah ini disampaikan dalam acara seminar Nasional Pusat Analisis Sosial Ekonomi dan Kebijakan Pertanian-Deptan PASEKP, Bogor, 21 Agustus.

Sugiyono, 2003. Metode Penelitian Administratif.. Bandung: Alfabeta.

Sugiyono, 2011. Metode Penelitian Kualitatif dan R\&D. Bandung : Alfabet

Sunaryanto, 2016. Newsletter Gemas Pesisir CCDP-IFAD, Tren Positif Budidaya Air Tawar di Pesisir, Satu Fenomena yang Menarik. Edisi Agustus-September 2016. Jakarta : KKP.

Tuwo, A. 2011. Pengelolaan Ekowisata Pesisir dan Laut, Pendekatan Ekologi, Sosial-Ekonomi, Kelembagaan, dan Sarana Wilayah. Sidoarjo : Brilian International.

Zawawi, A. 2016. Newsletter Gemas Pesisir CCDP-IFAD, Strategi Intervensi Pemasaran Produk Unggulan di Lokasi CCDP-IFAD Edisi 1-Juni 2016. Jakarta : KKP 